\title{
Diversity in food technology
}

A scientific review, farm-scale trials and extensive public consultations on genetically modified crops should pave the way for greater benefits and choice for consumers - provided that the organic movement abandons self-damaging dogmas.

ast week in England, the Lake District National Park Authority, like other British regions before it, declared itself a GM-free zone. This came close on the heels of a meeting between Margaret Beckett, the British secretary of state for the environment, food and rural affairs, and heads of major retail chains. She was left in little doubt of the retailers' resistance to stocking genetically modified (GM) foods on their shelves, given customers' antipathy.

Ironically, these events coincided with the publication of a rather more positive scientific assessment of GM crops (see Nature 424, 358; 2003). The review emphasized that, provided appropriate testing and regulation are in place for consideration on a case-by-case basis, GM crops hold out significant promise and leave little grounds for fear.

The next steps in the great British GM saga, which is being watched closely by many other countries, will be the publication of results of the farm-scale evaluation of oilseed rape, beet and maize, and the publication of the results of a major public consultation, both due in September. A final scientific review will then be produced for ministers. As the recently published review emphasizes, information from farm-scale evaluations is important in answering key questions about the effects of agricultural processes on wildlife.

The public debate warrants close scrutiny. The processes of consultations (some 40,000 responses) and public meetings (nearly 500 , in all) are complete. But only now has the scientific review addressed an agenda of concerns set by initial public consultations. The succinct information provided on the website of the public debate and at meetings does not do justice to the messages now available from the science review. Although much public concern is focused on issues of ownership and equity, the late timing of the science review limits the value of the public consultation on science-related issues.

More worryingly, open meetings in the public debate have been subjected to campaigning tactics by anti-GM lobbyists, leading to complaints from other members of the public that discussions have been compromised. So particular attention should be given to the independent evaluation of the consultation process.

The review left little doubt that the coexistence of GM and organic farming (assuming that approval for GM use is granted) will prove difficult to maintain. But the problem is an artificial one, based in essence on an ultimately arbitrary and self-defeating definition of 'contamination' by the organic movement.

Consider, for example, late blight in potatoes, a major problem for both conventional and organic farmers. Organic farmers contain the problem by applying copper sulphate-based preparations, which can harm the soil. Attempts to breed potatoes that are more resistant to the pathogen, Phytophthora infestans, have consistently failed to yield a marketable product. The best solution probably lies several years down the road in the next generation of GM crops.

British organic farmers - or at least the Soil Association, their campaigning organization - will resist seemingly to their dying breath the idea that inserting genes using molecular biology could be as ethical as the often less reliable but nevertheless technological approaches of conventional organic plant breeding and management. One can but hope that the messages from science will continue to be reassuring about the impacts of GM crops, and that they will combine with organic farmers' self-interest to demolish such phoney bastions, and allow both approaches to agriculture to prosper, in the ultimate interests of consumer benefits and choice.

\section{Dangers of privatization}

\section{The Bush administration's drive to contract out services is a threat to science.}

A $\mathrm{t}$ major US archaeological centres, the buzz at this time of year is typically about some exciting discovery of America's past uncovered on a summer dig. But visitors this year to the Midwest Archaeological Centre in Lincoln, Nebraska, and to the Southeast Archaeological Centre in Tallahassee, Florida, will encounter gloom. These institutions, which for decades have provided archaeological analysis for the US National Park Service and other agencies, may be entering their final days.

The two centres have found themselves among the targets of a plan by the President George W. Bush's administration to privatize as many federal jobs as possible before the November 2004 election (see page 478). The centres serve as premier resources for federal land management, but their advocates fear that they are being privatized precisely because of their wealth of expertise: their studies may delay or halt mining, logging or road-building.

Republicans deny that there is an ideological game afoot, only moves towards more efficiency. But recent experiences invite scepticism. During the process of analysing which jobs might be privatized, a consultant told government administrators that the archaeologists shouldn't be considered for privatization, as the centres' annual budgets are largely based on competitively secured projects. In other words, this is already lean science. But the consultant was told to keep his head down and avoid talking to congressional offices. A Republican Congressman from Nebraska described this appropriately as "a bean-counter doing something senseless".

An official at the Office of Management and Budget (OMB) told Nature that they have to consider archaeologists to be the same as laundry workers - not a sentiment likely to inspire confidence among Nature's readership. The OMB, after all, is the driving force behind the administration's privatization plans. Alarm bells should be sounding: the administration's zeal does not bode well for other agencies, with many scientists facing various degrees of privatization, including the National Institutes of Health and the Environmental Protection Agency.

Last week, administration officials backed away from some of their harsher privatization methods in the face of congressional opposition. Congress must continue to expose the Bush administration's privatization plans to tough scrutiny. 